\title{
Carbon, nitrogen, and organic matter of soil in an integrated crop- livestock system
}

\section{Eloisa Mattei ${ }^{1}$, Paulo Sérgio Rabello de Oliveira ${ }^{1}$, Leandro Rampim ${ }^{2}$, Carlos Augusto Rocha de Moraes Rego ${ }^{1}$, Jeferson Tiago Piano ${ }^{1}$, Marinez Carpiski Sampaio ${ }^{1}$}

\author{
${ }^{1}$ Universidade Estadual do Oeste do Paraná, Campus Marechal Cândido Rondon, Marechal Cândido Rondon, Paraná, Brasil. E-mail: \\ eloisa-mattei@hotmail.com, rabello.oliveira@hotmail.com, cassielcarlos@hotmail.com, jefersontpiano@hotmail.com, \\ mari_marinez@hotmail.com
}

${ }^{2}$ Universidade Estadual do Centro-Oeste, Campus CEDETEG, Guarapuava, Paraná, Brasil. E-mail: rampimleandro@ hotmail.com Received: 19/03/2020; Accepted: 27/07/2020.

\begin{abstract}
This study aimed to evaluate the effect of the integrated crop-livestock system on the contents and stocks of total organic carbon, total nitrogen, and soil organic matter. The experiment was carried out between April 2016 and February 2017, in a randomized block design in a strip-block scheme, with additional control treatment (fallow) and four repetitions. The treatments consisted of two densities of oat sowing (40 and $60 \mathrm{~kg} \mathrm{ha}^{-1}$ ) in strips A and different grazing frequencies (without grazing - WG, one grazing - $1 \mathrm{G}$, and two grazing - $2 \mathrm{G}$ ) in strips B, besides fallow as a control treatment. The determinations of the contents of total organic carbon (TOC), total nitrogen (TN), and organic matter $(\mathrm{SOM})$ were carried out in the soil layers of 0-5, 5-10, and 10-20 cm. Samplings were carried out after oat management, in the winter, and after soybean harvest, in the summer. The sowing density of black oats and the grazing frequencies were not able to promote changes in the total organic carbon and in the TOC stock, regardless of the time of evaluation. The use of $40 \mathrm{~kg} \mathrm{ha}^{-1}$ of oat seeds would be recommended, as it does not promote changes in the increase in MOS, thus generating savings in the acquisition of seeds. The use of the lowest density of oat without grazing and one grazing promoted changes on the total nitrogen in the 5-10 cm layer after the removal of oats, when compared to the fallow, and it presented content similar to the management with two grazings.
\end{abstract}

Keywords: Avena strigosa, grazing, no-tillage, integrated agricultural production system.

\section{Carbono, nitrogênio e matéria orgânica do solo em sistema de integração lavoura-pecuária}

\section{RESUMO}

O objetivo do presente estudo foi avaliar o efeito do sistema de integração lavoura-pecuária sobre os teores e estoques de carbono orgânico total, nitrogênio total e matéria orgânica do solo. O experimento foi realizado entre abril de 2016 e fevereiro de 2017, em delineamento de blocos casualizados em esquema de faixas, com testemunha adicional (pousio) e quatro repetições. Os tratamentos foram constituídos de duas densidades de semeadura de aveia $\left(40\right.$ e $60 \mathrm{~kg} \mathrm{ha}^{-1}$ ) nas faixas A e diferentes frequências de pastejo (sem pastejo - SP, um pastejo - 1P e dois pastejos - 2P) nas faixas B, além do pousio. As determinações dos teores de carbono orgânico total (COT), nitrogênio total (NT) e matéria orgânica (MOS) foram realizadas nas camadas de 0-5, 5-10 e 10-20 cm. Foram realizadas amostragens após os manejos da aveia, no período de inverno, e após a colheita da soja, no verão. A densidade de semeadura da aveia preta e as frequências de pastejo não foram capazes de promover alterações no carbono orgânico total e no estoque de COT, independente do momento da avaliação. A utilização de $40 \mathrm{~kg} \mathrm{ha}^{-1}$ de sementes de aveia seria recomendada, por não promover alteração no incremento de MOS, gerando, dessa forma, economia na aquisição de sementes. O emprego da menor densidade de aveia com frequências de SP e 1P promoveram alterações sobre o NT, na camada de 5-10 cm para a coleta após a saída da aveia, quando comparado ao pousio e este apresentou teor similar aos manejos $2 \mathrm{P}$.

Palavras-chave: Avena strigosa, pastejo, plantio direto, sistema integrado de produção agropecuária. 


\section{Introduction}

The chemical properties of the soil have a significant influence on the crop yield; however, when the soil is subjected to inadequate management, they can compromise agricultural activity. Monoculture and intensive mobilization are examples of inadequate management, as they reduce the contents of soil organic matter (SOM) and the availability of nutrients (Freitas et al., 2017).

The no-till system (NTS) and integrated croplivestock system (ICLS) are conservationist managements because they can maintain or increase the stock and fractions of carbon (Salton et al., 2011; Guareschi et al., 2013; Khorramdel et al., 2013; Rego et al., 2017), favoring the physical, chemical and biological properties of the soil (Chávez et al., 2011; Rosset et al., 2016).

Souza et al. (2009), evaluating grazing with moderate intensity in an integrated grass-soybean system conducted for ten years in NTS, found that they promoted an increase in total organic carbon (TOCS) and total nitrogen (TNS) stocks, similar what happened in notillage without grazing, however, when the grazing intensity was high, there were losses in the stocks of these elements.

The intensification of land use, as happens when the agropastoral system is adopted, can have negative impacts on soil properties if some precautions are not adopted. Variables such as forage species, density, and grazing frequency are not always properly investigated and may cause compaction and depletion of soil nutrients. Given the above, this study aimed to evaluate the effects of an integrated crop-livestock system on the contents and stocks of total organic carbon, total nitrogen, and soil organic matter.

\section{Material and Methods}

The study was carried out under field conditions, in the 2016/2017 harvest, at the Experimental Farm "Professor Antônio Carlos dos Santos Pessoa", belonging to the Western Paraná State University UNIOESTE, Campus of Marechal Cândido Rondon, the western Paraná, $24^{\circ} 31^{\prime} 58^{\prime \prime}$ S, $54^{\circ} 01^{\prime} 10^{\prime}$ 'W, and altitude of $400 \mathrm{~m}$.

The soil is classified as Latossolo Vermelho Eutroférrico (LVef) with a clayey texture (Santos et al., 2013). The region's climate, according to the Köppen classification, is of the Cfa-type, humid subtropical climate, with average temperatures varying between 17 ${ }^{\circ} \mathrm{C}$ and $19{ }^{\circ} \mathrm{C}$ and an average annual rainfall of $1,500 \mathrm{~mm}$ (Alvares et al., 2014). The climatic data for the experimental period (Figure 1) were obtained from the Automatic Climatological Station of the Nucleus of Experimental Stations of UNIOESTE, located near the experimental area.

The area was being managed in an integrated croplivestock system and under the same management (grazing and/or fallow in the winter period and soybean in the summer) for four years, under direct sowing. One year before the implementation of the experiment (2015), due to base saturation values was below $50 \%$, liming was carried out in the area, on the surface, with $3 \mathrm{Mg} \mathrm{ha}^{-1}$ of calcitic limestone, aiming to raise the base saturation to 70\%. In March 2016, soil sampling was performed for chemical characterization (Table 1).

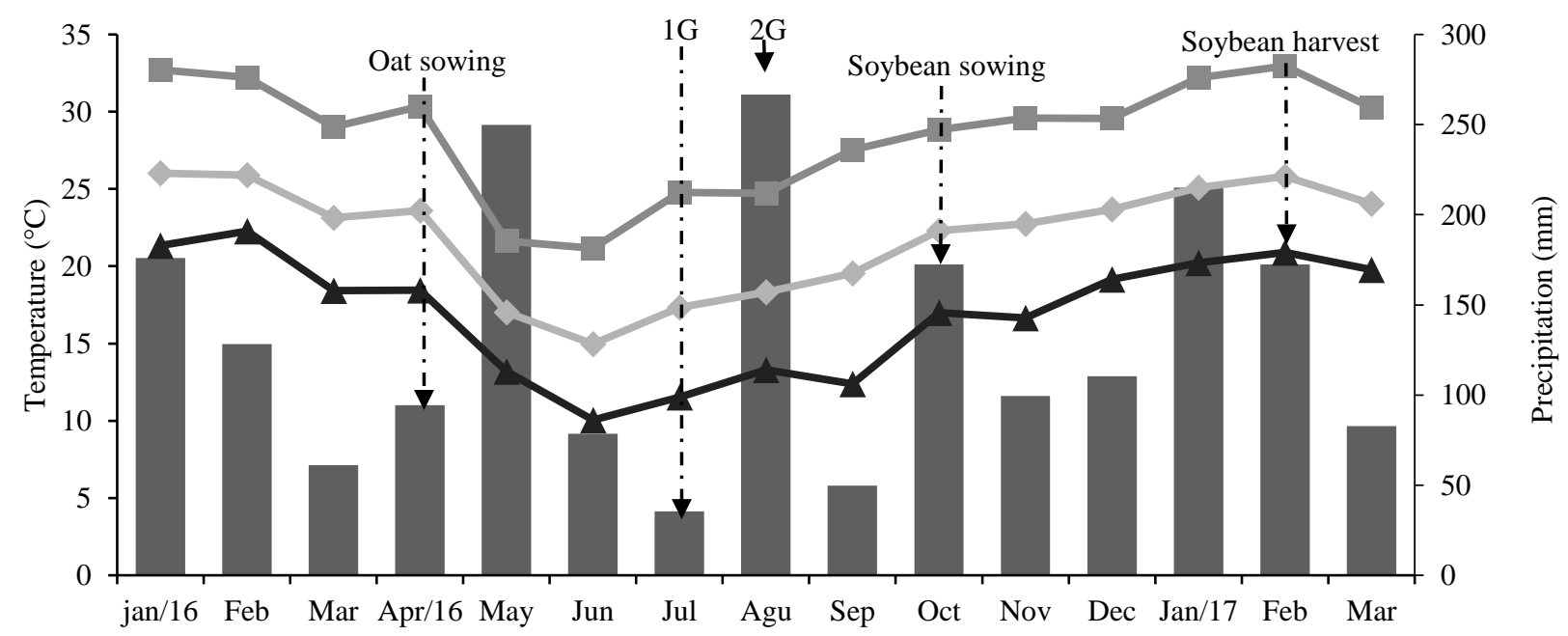

Precipitation $(\mathrm{mm}) \longrightarrow$ Average temp. $\quad \longrightarrow$ Maximum temp. $\quad \longrightarrow$ Minimum temp.

Figure 1. Monthly averages of maximum, average, and minimum air temperature and monthly accumulated rainfall during the period in which the experiment was conducted. 1P and 2G: first and second grazing of black oats in winter, 2016, respectively. Source: UNIOESTE, Marechal Cândido Rondon - PR. 
Table 1. Chemical and particle-size characteristics of the soil in the $0-0.10 \mathrm{~m}$ and $0.10-0.20 \mathrm{~m}$ layers, before the winter crop implantation.

\begin{tabular}{|c|c|c|c|c|c|c|c|c|c|c|}
\hline Layers & $\mathrm{P}$ & $\mathrm{OM}$ & $\mathrm{pH}$ & $\mathrm{H}+\mathrm{Al}$ & $\mathrm{Al}^{3+}$ & $\mathrm{K}^{+}$ & $\mathrm{Ca}^{2+}$ & $\mathrm{Mg}^{2+}$ & SB & CEC \\
\hline $\mathrm{m}$ & $\mathrm{mg} \mathrm{dm}{ }^{-3}$ & $\mathrm{~g} \mathrm{dm}^{-3}$ & $\mathrm{CaCl}_{2}$ & \multicolumn{7}{|c|}{ 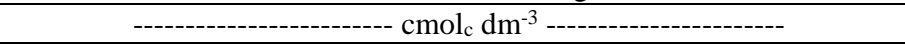 } \\
\hline $0-0.1$ & 32.72 & 39.64 & 4.20 & 6.82 & 0.40 & 0.58 & 3.89 & 2.92 & 7.39 & 14.21 \\
\hline $0.1-0.2$ & 21.14 & 23.24 & 4.63 & 5.92 & 0.15 & 0.55 & 4.59 & 2.67 & 7.81 & 13.73 \\
\hline Layers & \multicolumn{2}{|c|}{ BS } & $\mathrm{Cl}$ & & \multicolumn{3}{|c|}{ Silt } & \multicolumn{3}{|c|}{ Sand } \\
\hline $\mathrm{cm}$ & \multicolumn{2}{|c|}{$\%$} & \multicolumn{8}{|c|}{---------------------------------- g kg$^{-1}$} \\
\hline $0-0.1$ & \multicolumn{2}{|c|}{52.01} & \multicolumn{2}{|c|}{681.0} & \multirow{2}{*}{\multicolumn{3}{|c|}{266.5}} & \multirow{2}{*}{\multicolumn{3}{|c|}{$\begin{array}{l}52.5 \\
494\end{array}$}} \\
\hline $0.1-0.2$ & \multicolumn{2}{|c|}{56.88} & \multicolumn{2}{|c|}{751.5} & & & & & & \\
\hline
\end{tabular}

P and K: Mehlich-1 extractor; $\mathrm{Al}, \mathrm{Ca}$, and $\mathrm{Mg}: \mathrm{KCl}\left(1 \mathrm{~mol} \mathrm{~L}^{-1}\right)$ extractor; $\mathrm{H}+\mathrm{Al}$ : pH SMP (7.5). OM: Organic matter; SB: Sum of bases; CEC: Cation exchange capacity; BS: Base saturation.

A randomized block design in a strip-block scheme, with additional control treatment (fallow, with natural reseeding of ryegrass and forage radish) and four replications was used. In stripes A $(10 \times 18 \mathrm{~m})$, two sowing densities of the black oat crop (40 and $60 \mathrm{~kg} \mathrm{ha}^{-1}$ of seeds) and the fallow were allocated. In stripes B (5 x $20 \mathrm{~m}$ ), transversal to stripes A, the management of black oat was allocated: without grazing, one grazing, and two grazings, with a stubble height of $0.15-0.20 \mathrm{~m}$. The plots were formed by the combination of strips $\mathrm{A}$ and $\mathrm{B}(5 \mathrm{x}$ $10 \mathrm{~m}), 50 \mathrm{~m}^{2}$ and each block $(18 \times 30 \mathrm{~m})$ for $540 \mathrm{~m}^{2}$.

Thirty-days before the black oat implantation, the area was desiccated using Glyphosate-Isopropylamine + Clethodim salt at doses of $4.0 \mathrm{~L} \mathrm{ha}^{-1}$ and $0.5 \mathrm{~L} \mathrm{ha}^{-1}$ of a commercial product containing $480 \mathrm{~g} \mathrm{~L}^{-1}$ and $240 \mathrm{~g} \mathrm{~L}^{-1}$ of the active ingredient, respectively. The black oat crop was sown in the autumn/winter, in April 2016, in a mechanized and direct way over soybean straw, using 40 and $60 \mathrm{~kg} \mathrm{ha}^{-1}$ of black oat seeds, cultivar IAPAR 61, with $0.17 \mathrm{~m}$ of row spacing. The fertilization was performed using $250 \mathrm{~kg} \mathrm{ha}^{-1}$ of the NPK formulation 10:15:15 ( $\mathrm{N}, \quad \mathrm{P}_{2} \mathrm{O}_{5}$, and $\left.\mathrm{K}_{2} \mathrm{O}\right)$. For topdressing fertilization, $120 \mathrm{~kg} \mathrm{ha}^{-1}$ of $\mathrm{N}$, using urea as a source were applied.

The topdressing fertilization was carried out manually. In the treatment grazed twice, it was divided in three times, being an application at the beginning of tillering and the two others right after each grazing. For treatments grazed only once $(1 \mathrm{G})$ and those that were not grazed (without grazing), the nitrogen fertilizer in topdressing was split twice, with the first application in the oat tillering and the second after the first grazing. Regarding phytosanitary treatments, during the oat cycle, there was no need to apply herbicides, insecticides, and fungicides.

Aiming to achieve maximum productivity and the best quality of forage, the grazing started when oat plants had an average height of $30 \mathrm{~cm}$ (Fontaneli et al., 2012) (except in fallow and without grazing), using twelve animals of the Holstein breed in lactation, with an average weight of $650 \mathrm{~kg}$. The grazing was carried out for four hours daily, two in the morning and two in the afternoon, or until the stubble height reached about $15 \mathrm{~cm}$ so that there was no damage to the apical meristem of the plants. With the removal of animals, the area remained without grazing for 30 days to recover the productive potential of the oats, after which the second grazing was carried out similarly to the first. Grazing started at 86 and 116 days after sowing (DAS).

For the implantation of the summer crop, the area was previously desiccated, 36 days after the second grazing, using Glyphosate-Isopropylamine + Clethodim salt at the dose of $3.0 \mathrm{~L} \mathrm{ha}^{-1}$ and $0.40 \mathrm{~L} \mathrm{ha}^{-1}$ of a commercial product containing $480 \mathrm{~g} \mathrm{~L}^{-1}$ and $240 \mathrm{~g} \mathrm{~L}^{-1}$ of the active ingredient, respectively.

The sowing of soybeans was carried out in direct sowing over the straw system, in October 2016, about 20 days after desiccation, using the NIDERA 5909 RR cultivar. It was used $0.50 \mathrm{~m}$ of row spacing, $4 \mathrm{~cm}$ of sowing depth, and a density of 14 seeds per meter. For the fertilization, $310 \mathrm{~kg} \mathrm{ha}^{-1}$ of NPK formulation 02:20:18 $\left(\mathrm{N}, \mathrm{P}_{2} \mathrm{O}_{5}\right.$, and $\left.\mathrm{K}_{2} \mathrm{O}\right)$ were used.

Due to the crop development, applications of Pyraclostrobin + Fluxapyroxade fungicides were carried out at a dose of $300 \mathrm{~mL} \mathrm{ha}^{-1}$ of the commercial product; and insecticides: Neonicotinoid + Pyrethroid and Benzoylurea, at doses of $250 \mathrm{~mL} \mathrm{ha}^{-1}$ and $300 \mathrm{~mL} \mathrm{ha}^{-1}$ of a commercial product, respectively, with a spray volume of $250 \mathrm{~L} \mathrm{ha}^{-1}$. The soybean harvest was performed manually, on February 27, 2017.

The contents of total organic carbon and total nitrogen, stocks, and SOM were evaluated after the desiccation of oats and after soybean harvest. Four soil samples were collected per plot to constitute a representative composite sample, obtained with the aid of a Dutch auger, removed in the soil layers of 0-0.05, 0.050.10 , and $0.10-0.20 \mathrm{~m}$ depth.

After collection, the samples were packed in plastic bags, identified, and transported to the Soil Physics Laboratory of the Western Paraná State University, airdried, and passed through $2 \mathrm{~mm}$ sieves for analysis. The samples for determination of total nitrogen were sent directly to the freezer, where they remained until the beginning of the analysis.

The total organic carbon (TOC) was determined by the wet oxidation method with external heating, and the 
total nitrogen (TN) of the soil was determined by the Kjeldahl method after sulfuric digestion. Both determinations were adapted from Mendonça and Matos (2017).

The total carbon and nitrogen stocks of the soil were calculated according to the levels of TOC and TN, soil bulk density, and soil layer thickness (Santos et al., 2017). The soil organic matter (MOS) was determined by the loss-on-ignition method, proposed by Goldin (1987).

The data were submitted to analysis of variance by the F test $(\mathrm{p}<0.05)$. If there is significance, the Tukey test was applied at the level of $5 \%$ probability for the means concerning the comparisons between the different densities of oat sowing and grazing frequencies and the Dunnett test at the level of $5 \%$ for the means relative to the management concerning the fallow.

\section{Results and Discussion}

For the sampling carried out after the oat cultivation, it was found that regardless of the oat sowing density employed, the absence of grazing (without grazing) or the occurrence of only one grazing contributed to the total nitrogen content being higher than fallow in the 0.05-0.10 $\mathrm{m}$ soil layer (Table 2). However, in the evaluation carried out after soybean cultivation, there were no differences in oat management comparative to the fallow for the variables evaluated (Table 3).

The differences observed after oat cultivation for total nitrogen may be associated with the reduction of losses (greater absorption by the crop), the decomposition and release of the remaining residues (Mattei et al., 2018), and the chemical nitrogen fertilization carried out after the management. The increase in the availability of nitrogen for plants through these mechanisms favors absorption and meets, in part, the growing demand of the shoot (Silveira et al., 2012) after grazing by the animals.

Both after the winter crop management and after the soybean crop cycle, no significant changes were observed in the total organic carbon levels, due to the sowing density and the frequency of grazing adopted, and the highest levels were found in the layer $0-0.05 \mathrm{~m}$ (Tables 2 and 3). This result is associated with the accumulation of crop residues produced and deposited on the surface, as well as its decomposition, thus favoring the achievement of the highest contents in superficial layers.

The stocks of total organic carbon, the stocks of total nitrogen, and the soil organic matter content, after the management of oat and soybean crops, showed similar behavior, remaining practically constant until the 0-0.10 soil layer $m$ (Tables 2 and 3). This behavior can be explained by the greater deposition of crop residues on the soil surface, which was also observed by Silva et al., 2011; Batista et al., 2013; Ferreira et al., 2019.
Rego et al. (2017), evaluating total organic carbon contents in production systems, did not observe differences between integrated agricultural production systems versus non-integrated agricultural systems in the same layers analyzed in this study. On the other hand, when assessing grazing intensities in the ICL system, Souza et al. (2009) found that the total organic carbon was reduced when grazing occurred with a stubble height of $0.10 \mathrm{~m}$ comparing to the ungrazed area.

In the contents of total organic carbon, no differences were observed between the managements, ranging from 9.26 to $13.75 \mathrm{~g} \mathrm{~kg}^{-1}$, which may indicate that the adoption of managements in crop-livestock integration systems may be a viable alternative for keeping the soil producing throughout the year, providing income complementation and greater efficiency in the exploration of the area. According to Rodrigues et al. (2019), the integrated croplivestock system allows to increase the productivity of the production system, as well as to improve the conditions of producer and soil over the years.

Regarding the sowing density and grazing frequency in isolation, it was found that the frequencies (WG, $1 \mathrm{G}$, and $2 \mathrm{G}$ ) influenced the total nitrogen content of the soil in the 0-0.05 $\mathrm{m}$ and 0.05-0.10 $\mathrm{m}$ layers (Table 4). For the managements without grazing and with one grazing, no differences were observed, with the highest contents, $1.50 \mathrm{~g} \mathrm{~kg}^{-1}$ and $1.38 \mathrm{~g} \mathrm{~kg}^{-1}(0-0.05 \mathrm{~m}), 1.25 \mathrm{~g} \mathrm{~kg}^{-1}$ and $1.21 \mathrm{~g} \mathrm{~kg}^{-1}(0.05-0.10 \mathrm{~m})$, respectively, followed by the management with two grazings, with values of $1.12 \mathrm{~g} \mathrm{~kg}^{-}$ ${ }^{1}(0-0.05 \mathrm{~m})$ and $1.10 \mathrm{~g} \mathrm{~kg}^{-1}(0,05-0.10 \mathrm{~m})$ (Table 4).

Grazing frequencies also influenced the total nitrogen stock in the 0-0.05 $\mathrm{m}$ soil layer, in which the highest averages were observed in management without grazing and with one grazing (Table 4). For the 0.10-0.20 m layer, there was an interaction between the sources of variation, sowing density (D40 and D60), and grazing frequency, where the D40 associated with management with two grazings promoted a reduction in the total nitrogen stock of soil (Table 4).

The increase in total nitrogen stock of soil in management without grazing and with one grazing may be associated with the application of nitrogen in oat crop and the difference in the input of crop residue produced. In this study, where two grazings occurred, the amount of dry matter remaining was lower $\left(2,609.38 \mathrm{~kg} \mathrm{ha}^{-1}\right)$ than the other managements (WG: 7,250.00 kg ha-1 and $1 \mathrm{G}$ : $4,015.63 \mathrm{~kg} \mathrm{ha}^{-1}$ ), thus favoring the achievement of these results.

The lack of significance for the total nitrogen and its stock after the soybean harvest is due to the implantation in the whole area of this legume, which has $\mathrm{N}_{2}$ fixation capacity, favoring, in this way, the homogeneity in the quantity and total nitrogen stock in the experimental area (Table 3). The use of legumes provides changes in nitrogen levels, being observed by Silva et al. (2011) and Ferreira et 
al. (2019), that the cultivation of legumes in rotation with grasses increased nitrogen in the superficial soil layers. Soil organic matter had similar results after oat management and after soybean harvest (Tables 2 and 3). However, it was observed that the seeding density used and the adopted managements influenced the soil organic matter content in the $0.10-0.20 \mathrm{~m}$ soil layer (Table 3 and 4).

The lower sowing density without grazing provided soil organic matter content $15.4 \%$ higher than the use of the density of $60 \mathrm{~kg} \mathrm{ha}^{-1}$ in the same situation, as well as the lower sowing density without grazing and with two grazings, did not change the soil organic matter contents in deeper layers. Such results may indicate a lower cost in the pasture formation without changing the levels of soil organic matter, as it will provide less competition for production factors and benefits in the pasture formation.

According to Salton et al. (2011), the crop-livestock integration systems under no-tillage promote a differentiated contribution of plant residues comparing to the conventional systems, solely of grains, either on the surface or subsurface, a fact that may have contributed to obtaining the largest organic matter contents along with the soil profile.

It was also verified that the sowing density influenced the soil organic matter content in the 0.05-0.10 m layer, since, when $40 \mathrm{~kg} \mathrm{ha}^{-1}$ of oat seeds were used, the amount of organic matter was higher $(12.08 \%)$ than $60 \mathrm{~kg} \mathrm{ha}^{-1}$ (11.90\%), regardless of the management adopted (Table 4).

The organic matter is a soil attribute that is influenced by several factors; among them, the object of study, the amount of crop residues contributed to the soil, and the adopted management, since the way the animals distribute their waste in the area can also influence these results. Where grazing did not occur, possibly, these residues were better distributed, presenting a more uniform microbial activity.

Table 2. Total nitrogen in the soil $\left(\mathrm{g} \mathrm{kg}^{-1}\right)$, total nitrogen stock $\left(\mathrm{Mg} \mathrm{ha}^{-1}\right)$, total organic carbon $\left(\mathrm{g} \mathrm{kg}^{-1}\right)$, total organic carbon stock (Mg $\mathrm{ha}^{-1}$ ) and soil organic matter $(\%)$ in an integrated crop-livestock system with different managements after oat cultivation, in the $0-0.05$, $0.05-0.10$, and $0.10-0.20 \mathrm{~m}$ soil layers

\begin{tabular}{|c|c|c|c|c|c|c|}
\hline \multirow[t]{2}{*}{ Management } & \multicolumn{3}{|c|}{$\begin{array}{l}\text { Total nitrogen } \\
\quad\left(\mathrm{g} \mathrm{kg}^{-1}\right)\end{array}$} & \multicolumn{3}{|c|}{$\begin{array}{l}\text { Total nitrogen stock } \\
\left(\mathrm{Mg} \mathrm{ha}^{-1}\right)\end{array}$} \\
\hline & $0-0.05 \mathrm{~m}$ & $0.05-0.1 \mathrm{~m}$ & $0.1-0.2 \mathrm{~m}$ & $0-0.05 \mathrm{~m}$ & $0.05-0.1 \mathrm{~m}$ & $0.1-0.2 \mathrm{~cm}$ \\
\hline $\begin{array}{l}\text { Fallow } \\
\quad \vdots\end{array}$ & 1.30 & 1.10 & 1.20 & 6.90 & 7.20 & 15.00 \\
\hline 40 Without grazing & 1.43 & $1.24^{+}$ & 1.28 & 8.21 & 7.85 & 16.65 \\
\hline 401 grazing & 1.30 & $1.20^{+}$ & 1.27 & 7.76 & 7.53 & 15.69 \\
\hline 402 grazing & 1.10 & $1.14^{\mathrm{ns}}$ & 1.12 & 5.93 & 9.49 & 11.20 \\
\hline 60 Without grazing & 1.57 & $1.26^{+}$ & 1.32 & 8.41 & 8.44 & 17.82 \\
\hline 601 grazing & 1.33 & $1.22^{+}$ & 1.32 & 7.65 & 7.98 & 17.33 \\
\hline 602 grazing & 1.28 & $1.07^{\mathrm{ns}}$ & 1.27 & 6.83 & 6.72 & 16.53 \\
\hline Average & 1.30 & 1.20 & 1.30 & 7.40 & 7.90 & 15.70 \\
\hline \multirow[t]{2}{*}{ Management } & \multicolumn{3}{|c|}{$\begin{array}{l}\text { Total organic carbon } \\
\qquad\left(\mathrm{g} \mathrm{kg}^{-1}\right)\end{array}$} & \multicolumn{3}{|c|}{$\begin{array}{l}\text { Total organic carbon stock } \\
\left(\mathrm{Mg} \mathrm{ha}^{-1}\right)\end{array}$} \\
\hline & $0-0.05 \mathrm{~m}$ & $0.05-0.1 \mathrm{~m}$ & $0.1-0.2 \mathrm{~m}$ & $0-0.05 \mathrm{~m}$ & $0.05-0.1 \mathrm{~m}$ & $0.1-0.2 \mathrm{~m}$ \\
\hline $\begin{array}{l}\text { Fallow } \\
\vdots\end{array}$ & 13.00 & 11.70 & 11.20 & 7.10 & 7.50 & 14.00 \\
\hline 40 Without grazing & 13.75 & 11.84 & 10.41 & 7.71 & 7.51 & 13.56 \\
\hline 401 grazing & 13.37 & 11.84 & 12.32 & 7.58 & 7.40 & 15.23 \\
\hline 402 grazing & 12.32 & 11.08 & 12.32 & 6.85 & 7.31 & 15.16 \\
\hline 60 Without grazing & 13.08 & 12.22 & 12.13 & 7.07 & 8.19 & 16.27 \\
\hline 601 grazing & 12.51 & 12.32 & 11.84 & 6.88 & 8.02 & 15.57 \\
\hline 602 grazing & 11.94 & 11.36 & 12.22 & 6.62 & 7.04 & 15.90 \\
\hline Average & 12.90 & 11.80 & 11.80 & 7.10 & 7.60 & 15.10 \\
\hline \multirow{2}{*}{ Management } & \multicolumn{6}{|c|}{ Organic matter $(\%)$} \\
\hline & \multicolumn{2}{|c|}{$0-0.05 \mathrm{~m}$} & \multicolumn{2}{|r|}{$0.05-0.1 \mathrm{~m}$} & \multicolumn{2}{|r|}{$0.1-0.2 \mathrm{~m}$} \\
\hline $\begin{array}{l}\text { Fallow } \\
\vdots\end{array}$ & \multicolumn{2}{|c|}{12.10} & \multicolumn{2}{|r|}{11.80} & \multicolumn{2}{|r|}{12.00} \\
\hline 40 Without grazing & \multicolumn{2}{|c|}{12.68} & \multicolumn{2}{|r|}{12.17} & \multicolumn{2}{|r|}{13.78} \\
\hline 401 grazing & \multicolumn{2}{|c|}{12.24} & \multicolumn{2}{|r|}{11.98} & \multicolumn{2}{|r|}{11.94} \\
\hline 402 grazing & \multicolumn{2}{|c|}{11.67} & \multicolumn{2}{|r|}{12.09} & \multicolumn{2}{|r|}{12.25} \\
\hline 60 Without grazing & \multicolumn{2}{|c|}{12.14} & \multicolumn{2}{|r|}{12.06} & \multicolumn{2}{|r|}{11.94} \\
\hline 601 grazing & \multicolumn{2}{|c|}{12.78} & \multicolumn{2}{|r|}{11.99} & \multicolumn{2}{|r|}{12.04} \\
\hline 602 grazing & \multicolumn{2}{|c|}{12.30} & \multicolumn{2}{|r|}{11.64} & & 12.00 \\
\hline Average & & & & 12.00 & & 12.30 \\
\hline
\end{tabular}

${ }^{{ }^{\prime}}$ : significant and superior to the fallow by Dunnett's test, at 5\% probability level; ' $:$ significant and inferior to the fallow by Dunnett's test, at 5\% probability level; ns: not significant by Dunnett's test, at 5\% probability level. 40 and 60: sowing densities of 40 and $60 \mathrm{~kg}$ $\mathrm{ha}^{-1}$ of oat seeds. 
Table 3. Total nitrogen in the soil $\left(\mathrm{g} \mathrm{kg}^{-1}\right)$, total nitrogen stock $\left(\mathrm{Mg} \mathrm{ha}^{-1}\right)$, total organic carbon $\left(\mathrm{g} \mathrm{kg}^{-1}\right)$, total organic carbon stock (Mg $\mathrm{ha}^{-1}$ ) and soil organic matter $(\%)$ in an integrated crop-livestock system with different managements after soybean harvest, in the 0 $0.05,0.05-0.10$ and $0.10-0.20 \mathrm{~m}$ soil layers.

\begin{tabular}{|c|c|c|c|c|c|c|}
\hline \multirow[t]{2}{*}{ Management } & \multicolumn{3}{|c|}{$\begin{array}{l}\text { Total nitrogen } \\
\qquad\left(\mathrm{g} \mathrm{kg}^{-1}\right)\end{array}$} & \multicolumn{3}{|c|}{$\begin{array}{l}\text { Total nitrogen stock } \\
\qquad\left(\mathrm{Mg} \mathrm{ha}^{-1}\right)\end{array}$} \\
\hline & $0-0.05 \mathrm{~m}$ & $0.05-0.1 \mathrm{~m}$ & $0.1-0.2 \mathrm{~m}$ & $0-0.05 \mathrm{~m}$ & $0.05-0.1 \mathrm{~m}$ & $0.1-0.2 \mathrm{~m}$ \\
\hline $\begin{array}{c}\text { Fallow } \\
\vdots\end{array}$ & 1.20 & 1.10 & 1.10 & 7.20 & 6.80 & 13.80 \\
\hline 40 Without grazing & 1.39 & 1.14 & 1.09 & 7.62 & 7.52 & 14.14 \\
\hline 401 grazing & 1.41 & 1.09 & 1.17 & 8.29 & 7.13 & 14.48 \\
\hline 402 grazing & 1.28 & 1.08 & 1.13 & 7.77 & 6.77 & 14.01 \\
\hline 60 Without grazing & 1.37 & 1.16 & 1.18 & 7.81 & 7.26 & 14.03 \\
\hline 601 grazing & 1.37 & 1.12 & 1.19 & 8.82 & 7.30 & 15.12 \\
\hline 602 grazing & 1.31 & 1.17 & 1.15 & 8.20 & 7.30 & 14.49 \\
\hline Average & 1.30 & 1.10 & 1.10 & 8.00 & 7.10 & 14.30 \\
\hline \multirow[t]{2}{*}{ Management } & \multicolumn{3}{|c|}{$\begin{array}{l}\text { Total organic carbon } \\
\qquad\left(\mathrm{g} \mathrm{kg}^{-1}\right)\end{array}$} & \multicolumn{3}{|c|}{$\begin{array}{c}\text { Total organic carbon stock } \\
\left(\mathrm{Mg} \mathrm{ha}^{-1}\right)\end{array}$} \\
\hline & $0-0.05 \mathrm{~m}$ & $0.05-0.1 \mathrm{~m}$ & $0.1-0.2 \mathrm{~m}$ & $0-0.05 \mathrm{~m}$ & $0.05-0.1 \mathrm{~m}$ & $0.1-0.2 \mathrm{~m}$ \\
\hline $\begin{array}{c}\text { Fallow } \\
\vdots\end{array}$ & 10.80 & 10.40 & 11.40 & 5.90 & 6.70 & 14.30 \\
\hline 40 Without grazing & 12.41 & 10.60 & 10.98 & 7.21 & 6.70 & 14.32 \\
\hline 401 grazing & 12.41 & 10.60 & 10.69 & 7.15 & 6.65 & 13.26 \\
\hline 402 grazing & 13.75 & 10.60 & 11.17 & 7.65 & 6.99 & 13.80 \\
\hline 60 Without grazing & 11.55 & 10.69 & 9.26 & 6.24 & 7.18 & 12.45 \\
\hline 601 grazing & 11.75 & 11.46 & 9.55 & 6.48 & 7.44 & 12.56 \\
\hline 602 grazing & 11.94 & 10.22 & 11.46 & 6.58 & 6.38 & 14.92 \\
\hline Average & 12.10 & 10.70 & 10.60 & 6.70 & 6.90 & 13.70 \\
\hline \multirow{2}{*}{ Management } & \multicolumn{6}{|c|}{ Soil organic matter (\%) } \\
\hline & \multicolumn{2}{|c|}{$0-0.05 \mathrm{~m}$} & \multicolumn{2}{|r|}{$0.05-0.1 \mathrm{~m}$} & \multicolumn{2}{|r|}{$0.1-0.2 \mathrm{~m}$} \\
\hline $\begin{array}{l}\text { Fallow } \\
\vdots\end{array}$ & \multicolumn{2}{|c|}{12.20} & \multicolumn{2}{|r|}{11.70} & \multicolumn{2}{|r|}{12.30} \\
\hline 40 Without grazing & \multicolumn{2}{|c|}{12.87} & \multicolumn{2}{|r|}{12.08} & \multicolumn{2}{|r|}{12.14} \\
\hline 401 grazing & \multicolumn{2}{|c|}{12.34} & \multicolumn{2}{|r|}{11.67} & \multicolumn{2}{|r|}{11.99} \\
\hline 402 grazing & \multicolumn{2}{|c|}{12.43} & \multicolumn{2}{|r|}{11.79} & \multicolumn{2}{|r|}{11.86} \\
\hline 60 Without grazing & \multicolumn{2}{|c|}{12.34} & \multicolumn{2}{|r|}{11.89} & \multicolumn{2}{|r|}{12.17} \\
\hline 601 grazing & \multicolumn{2}{|c|}{12.36} & \multicolumn{2}{|r|}{12.04} & \multicolumn{2}{|r|}{13.05} \\
\hline 602 grazing & \multicolumn{2}{|c|}{12.39} & \multicolumn{2}{|r|}{11.98} & & 10.79 \\
\hline Average & & & & 11.90 & & 12.00 \\
\hline
\end{tabular}

${ }^{+}:$significant and superior to the fallow by Dunnett's test, at 5\% probability level; : : significant and inferior to the fallow by Dunnett's test, at $5 \%$ probability level; ns: not significant by Dunnett's test, at 5\% probability level. 40 and 60: sowing densities of 40 and $60 \mathrm{~kg}^{-1} \mathrm{of}^{-}$oat seeds.

Table 4. Total nitrogen, total nitrogen stock, and soil organic matter conducted in an integrated crop-livestock system, in the $0-0.05$, 0.05-0.10, and 0.10-0.20 m layers, after oat cultivation.

\begin{tabular}{|c|c|c|c|c|c|c|c|c|c|}
\hline \multicolumn{10}{|c|}{ Total nitrogen $\left(\mathrm{g} \mathrm{kg}^{-1}\right)$} \\
\hline \multirow{2}{*}{ Management } & \multicolumn{3}{|c|}{------ 0-0.05 m ------ } & \multicolumn{3}{|c|}{----- 0.05-0.10 m ------ } & \multicolumn{3}{|c|}{ - } \\
\hline & D40 & D60 & Average & D40 & D60 & Average & D40 & D60 & Average \\
\hline SP & 1.43 & 1.57 & $1.50 \mathrm{a}$ & 1.24 & 1.26 & $1.25 \mathrm{a}$ & 1.28 & 1.32 & 1.30 \\
\hline $1 \mathrm{P}$ & 1.28 & 1.47 & $1.38 \mathrm{a}$ & 1.20 & 1.22 & $1.21 \mathrm{a}$ & 1.27 & 1.32 & 1.29 \\
\hline $2 \mathrm{P}$ & 1.11 & 1.14 & $1.12 \mathrm{~b}$ & 1.14 & 1.07 & $1.10 \mathrm{~b}$ & 1.12 & 1.27 & 1.19 \\
\hline Average & $1.28 \mathrm{~B}$ & $1.39 \mathrm{~A}$ & & 1.19 & 1.18 & & 1.22 & 1.30 & \\
\hline \multicolumn{10}{|c|}{ Total nitrogen stock $\left(\mathrm{Mg} \mathrm{ha}^{-1}\right)$} \\
\hline \multirow{2}{*}{ Management } & \multicolumn{3}{|c|}{------ 0-0.05 m ------ } & \multicolumn{3}{|c|}{---- 0.05-0.10 m ----- } & \multicolumn{3}{|c|}{ - - 0.10-0.20 ------- } \\
\hline & $\mathrm{D} 40$ & D60 & Average & D40 & D60 & Average & D40 & D60 & Average \\
\hline SP & 8.21 & 8.41 & $8.31 \mathrm{a}$ & 7.85 & 8.44 & 8.14 & $16.65 \mathrm{aA}$ & $17.82 \mathrm{aA}$ & 17.23 \\
\hline $1 \mathrm{P}$ & 7.52 & 8.18 & $7.85 \mathrm{ab}$ & 7.53 & 7.98 & 7.75 & $15.69 \mathrm{aA}$ & $17.33 \mathrm{aA}$ & 16.51 \\
\hline $2 \mathrm{P}$ & 6.16 & 6.31 & $6.23 \mathrm{~b}$ & 9.49 & 6.72 & 8.11 & $11.20 \mathrm{bB}$ & $16.53 \mathrm{aA}$ & 13.87 \\
\hline Average & 7.30 & 7.63 & & 8.28 & 7.71 & & 14.51 & 17.23 & \\
\hline \multicolumn{10}{|c|}{ Soil organic matter $(\%)$} \\
\hline \multirow{2}{*}{ Management } & \multicolumn{3}{|c|}{------- 0-0.05 m ------ } & \multicolumn{3}{|c|}{---- 0.05-0.10 m ------ } & \multicolumn{3}{|c|}{-------- 0.10-0.20 -------- } \\
\hline & D40 & D60 & Average & D40 & D60 & Average & D40 & D60 & Average \\
\hline SP & 12.68 & 12.14 & 12.41 & 12.17 & 12.06 & 12.12 & $13.78 \mathrm{aA}$ & $11.94 \mathrm{aB}$ & 12.86 \\
\hline $1 \mathrm{P}$ & 12.24 & 12.78 & 12.51 & 11.98 & 11.99 & 11.99 & $11.94 \mathrm{bA}$ & $12.04 \mathrm{aA}$ & 11.99 \\
\hline $2 \mathrm{P}$ & 11.67 & 12.30 & 11.98 & 12.09 & 11.64 & 11.87 & $12.25 \mathrm{abA}$ & $12.00 \mathrm{aA}$ & 12.12 \\
\hline Average & 12.19 & 12.41 & & $12.08 \mathrm{~A}$ & 11.90B & & 12.65 & 11,99 & \\
\hline
\end{tabular}

Means followed by the same lowercase letter in the column and uppercase in the line do not differ statistically by the Tukey test (5\%). D40 and D60: sowing densities of 40 and $60 \mathrm{~kg} \mathrm{ha}^{-1}$ of oat seeds, respectively; WG: without grazing, 1P: one grazing, 2P: two grazings. 


\section{Conclusions}

The sowing density of black oats and/or the management were not able to promote changes in the total organic carbon and in the total organic carbon stock, regardless of the moment of the evaluation.

The use of $40 \mathrm{~kg} \mathrm{ha}^{-1}$ of oat seeds is recommended, as it does not promote changes in the increase of organic matter in the soil, thus generating savings in the acquisition of seeds.

The managements with two grazings and fallow had equal total nitrogen content in the $0.05-0.10 \mathrm{~m}$ soil layer.

\section{Acknowledgements}

The authors would like to thank CNPq for granting a research productivity grant (process 302300/2017-1) granted to researcher Dr. Paulo Sérgio Rabello de Oliveira and research productivity grant (process 305855/2017-4) granted to researcher Dr. Leandro Rampim, to the CAPES and the Fundação Araucária for granting a scholarship.

\section{Bibliographic References}

Alvares, C.A., Stape, J.L., Sentelhas, P.C., Gonçalves, J.L.M., Sparovek, G., 2014. Köppen's climate classification map for Brazil. Meteorologische Zeitschrift, 22(6), 711-728. DOI: 10.1127/0941-2948/2013/0507.

Batista, I., Pereira, M.G., Correia, M.E.F., Bieluczyk, W., Schiavo, J.A., Rows, J.R.C., 2013. Teores e estoque de carbono em frações lábeis e recalcitrantes da matéria orgânica do solo sob integração lavoura-pecuária no bioma Cerrado. Semina: Ciências Agrárias, 34(6), 3377-3388. DOI: 10.5433/16790359.2013v34n6Supl1p3377.

Chávez, L.F., Escobar, L.F., Anghinoni, I., Carvalho, P.C.F., Meurer, E.J., 2011. Diversidade metabólica e atividade microbiana no solo em sistema de integração lavoura-pecuária sob intensidades de pastejo. Pesquisa Agropecuária Brasileira, Brasília, 46(10), 1254-1261. DOI: 10.1590/S0100204X2011001000020.

Ferreira, G.A., Alves, S.J., Oliveira, P.S.R, Costa, A.C.T., Nolla, A., 2019. Carbono orgânico e nitrogênio do solo sob alturas de pastejo da Urochloa ruziziensis em sistema agropastoril. Revista de Ciências Agroveterinárias, 18(3), 252 262. DOI: $10.5965 / 223811711832019352$.

Fontaneli, R.S., Santos, H.P., Fontaneli, R.S., 2012. Forrageiras para integração lavoura-pecuária-floresta na Região Sul Brasileira. Brasília, Embrapa.

Freitas, L., Oliveira, I.A., Silva, L.S., Frare, C.V., Filla, V.A., Gomes, R.P., 2017. Indicators of the chemical and physical quality of the soil under different management systems. Unimar Ciências, 26(1-2), 8-25.

Goldin, A., 1987. Reassessing the use of loss-on-ignition for estimating organic matter content in noncalcareous soils. Communications in Soil Science and Plant Analysis, 18(10), 1111-1116. DOI: 10.1080/00103628709367886.
Guareschi, R.F., Pereira, M.G., Perin, A., 2013. Frações da matéria orgânica em áreas de Latossolo sob diferentes sistemas de manejo no Cerrado do estado de Goiás. Semina: Ciências Agrárias, 34(6), 2615-2628. DOI: 10.5433/16790359.2013v34n6p2615

Khorramdel, S., Koocheki, A., Mahallati, M.N., Khorasani, R., Ghorbani, R., 2013. Evaluation of carbon sequestration potential in corn fields with different management systems. Soil \& Tillage Research, 133(1), 25-31. DOI: 10.1016/j.still.2013.04.008.

Mattei, E., Oliveira, P.S.R., Rampim, L., Egewarth, J.F., Rego, C.A.R.M., Piano, J.T., Herrera, J.L., 2018. Remaining straw and release of nutrients from oat managed in integrated croplivestock. Bioscience Journal, 34(6), 206-215. DOI: 10.14393/BJ-v34n6a2018-42036.

Mendonça, E.S., Matos, E.S., 2017. Matéria orgânica do solo: métodos de análises, segunda ed. Viçosa, UFV/Gefert.

Rego, C.A.R.M., Egewarth, J.F., Francziskowski, M.A., Cremonez, F.E., Oliveira, P.S.R., Lana, M.C., Costa, B.P., Mattei, E., Sampaio, M.C., Egewarth, V.A., Herrera, J.L., 2017. Quantification of the carbono contente of the fractions of humic substances ant total organic carbono in diferente production systems. Journal of Agricultural Science, 9(3) 1-8. DOI: 10.5539/jas.v9n12p152.

Rodrigues, L.M., Teodoro, A.G., Santos, A.J.M., Backes, C., Rocha, J.H.T., Giongo, P.R., Santos, Y.L.A., 2019. Integração Lavoura-Pecuária-Floresta: Interação entre Componentes e Sustentabilidade do Sistema. Archivos de Zootecnia, 68(263), 448-455. DOI: 10.21071/az.v68i263.4207.

Rosset, J.S., Lana, M.C., Pereira, M.G., Schiavo, J.A., Rampim, L., Sarto, M.V.M., 2016. Chemical and oxidizable fractions of soil organic matter under different management systems in an Oxisol. Pesquisa Agropecuária Brasileira, 51(9), 1529-1538. DOI: 10.1590/s0100-204x2016000900052.

Salton, J.C., Mielniczuk, J., Bayer, C., Fabrício, A.C., Macedo, M.C.M., Broch, D.L., 2011. Teor e dinâmica do carbono no solo em sistemas de integração lavoura-pecuária. Pesquisa Agropecuária Brasileira, 46(10), 1349-1356. DOI: 10.1590/S0100-204X2011001000031.

Santos, F.A.S., Pierangeli, M.A.P., Silva, F.L., 2017. Dynamics of soils organic carbon under pastures in fields of murundus. Revista Scientia Agraria, Curitiba, 18(2), 43-53. DOI: 10.5380/rsa.v18i2.50662.

Santos, H.G., Jacomine, P.K.T., Anjos, L.H.C., Oliveira, V.A., Lumbreras, J.F., Coelho, M.R., Almeida, J.A., Cunha, T.J.F., Oliveira, J.B., 2013. Sistema Brasileiro de Classificação de Solos, terceira ed. Brasília, Embrapa.

Silva, E.F., Lourente, E.P.R., Marchetti, M.E., Mercante, F.M., Ferreira, A.K.T., Fujii, G.C., 2011. Frações lábeis e recalcitrantes da matéria orgânica em solos sob integração lavoura-pecuária. Pesquisa Agropecuária Brasileira, 46(10), 1321-1331. DOI: 10.1590/S0100-204X2011001000028.

Silveira, E.R., Pelissari, A., Moraes, A., Piazzetta, H.V.L., Lang, C.R., Carvalho, P.C.F., 2012. Intensidade de pastejo e a adubação nitrogenada na massa seca de aveia e produtividade do milho na integração lavoura-pecuária. Semina: Ciências Agrárias, 33(4), 1323-133. DOI: 10.5433/16790359.2012v33n4p1323. 
Souza, E.D., Costa, S.E.V.G.A., Anghinoni, I., Carvalho, P.C.F., Andrigueti, M., Cao, E., 2009. Estoques de Carbono Orgânico e de Nitrogênio no solo em sistema de integração lavoura-pecuária em plantio direto, submetido a intensidades de pastejo. Revista Brasileira de Ciência do Solo, 33(3), 1829-183. DOI: $10.1590 / \mathrm{S} 0100-06832009000600031$. 